\title{
The Strategic Role of Correctional Advisers in the Implementation of Narcotics Rehabilitation for Prisoners
}

\author{
Insan Firdaus $^{1}$, Haryono ${ }^{1}$, Hakki Fajriando ${ }^{1}$, Nurangga Firmanditya ${ }^{1}$ \\ ${ }^{I}$ The Agency of Research and Development of Law and Human Rights of the Ministry of Law and Human Rights of The Republic \\ of Indonesia Jakarta, Indonesia \\ Corresponding author: insanfirdaus11@gmail.com
}

\begin{abstract}
Based on the prison database records, most of the prisoners in the correctional institution in Indonesiaan are narcotics convicts. Interestingly, many of these prisoners are addicts, abusers, and victims of drug abuse who must be rehabilitated immediately to recover from drug addiction. This is what encourages correctional institutions to carry out narcotics rehabilitation for inmates. However, according to research results from the Research and Development Agency for Law and Human Rights, the implementation of narcotics rehabilitation at the correctional unit has not been effective because it has not been on target and implemented in an integrated and sustainable manner. One of the causes is the inadequate role of correctional advisers in the narcotics rehabilitation process. Therefore, the aim of this study is to determine the role of correctional advisers in the narcotics rehabilitation process. This study uses a qualitative and descriptive approach. Correctional advisers have an important role in every stage of narcotics rehabilitation. Correctional advisers have the duties and functions to verify, provide assistance, guidance and act as addiction consultants to supervise the development of rehabilitation of prisoners who participate in rehabilitation. This role is to ensure the accuracy of targeting and the sustainability of the rehabilitation phase. Therefore, to optimize the role of the Correctional adviser, the Director General of Correctional must increase the capacity and competence of correctional adviser.
\end{abstract}

Keywords: correctional advisers, narcotics, rehabilitation.

\section{INTRODUCTION}

The trafficking of narcotics and narcotics abuse is legal and societal problems that occur in almost all countries, including Indonesia. Various efforts have been made to eradicate and prevent narcotics crime, both through the process of law enforcement and providing education on the dangers of narcotics to the community. Data from the National Narcotics Agency recorded that in $2018,59,533$ people were suspected of criminal narcotics cases [1]. This dominance of narcotics cases does not only occur in Indonesian prisons. Several other studies in several countries show that the percentage of prisoners who have drug problems ranges from 40 to $80 \%$.[3]. condition has a direct impact on the increase in the number of residents of detention centers and prisons, causing prison overcrowding.

Based on the correctional database system, as of June 2020, 230,605 people were incarcerated in Indonesian detention centers and prisons. The prisoners for narcotics offenses were recorded at 134,710 or about $58 \%$ of the total of national prisoners[2]. The 


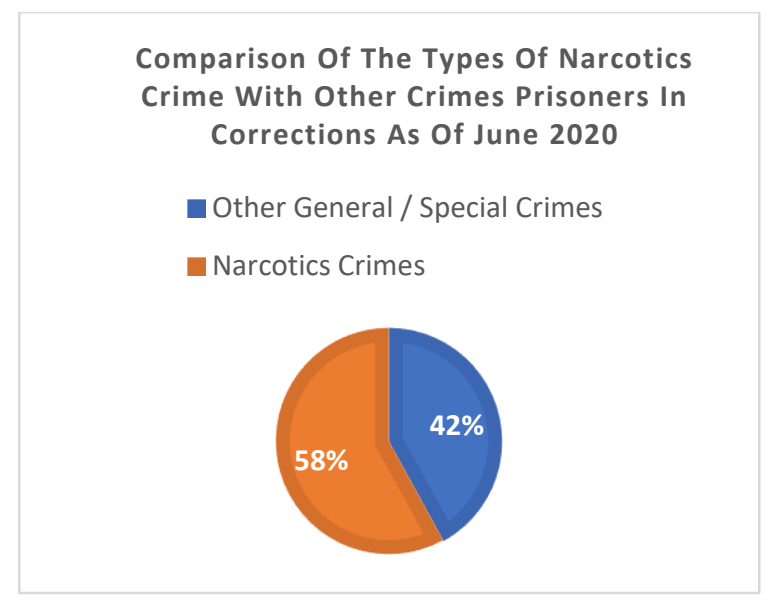

Source: Implementation Guidelines for Narcotics Rehabilitation at the Correctional Unit.

The impact of the increasing number of prisoners of narcotics crime causes other problems in detention centers and prisons, such as the circulation of narcotics controlled by prisoners as well as the distribution and narcotics consumption by prisoners in detention centers and prisons, as well as health problems due to drug addiction.[4].

Indonesian penitentiary systems divide narcotics crime convicts into 2 categories. The first category consisted of narcotics dealers/traffickers, while narcotics users comprised the second category. These categories are necessary as a basis for the process of placing and fostering prisoners. In line with Law Number 35 of 2009 concerning Narcotics, the treatment of detainees and prisoners in detention centers and correctional institutions uses two approaches. First, the hard approach for traffickers and dealers with an emphasis on security factors and a deterrent effect . Second, soft approach for users so that these prisoners can recover from drug dependence through narcotics rehabilitation programs.

Rehabilitation of narcotics is urgently needed by prisoners who are categorized as addicts, abusers, and victims of narcotics abuse because they are narcotics criminal offenders who are also victims of their own actions/mistakes [5]. Because of this, these prisoners are categorized as patients, considering that narcotics addiction is a disease that must be treated both medically, psychologically, and socially so that punishment against them is not only to provide a deterrent effect but more importantly helping them recover from drug addictions.

If not rehabilitated, prisoners who are still addicted to narcotics will try to obtain narcotics and use within a correctional facility. This is strengthened from various studies that estimate that the percentage of individuals reporting problematic substance misuse is comparatively higher in prison than in the community. Drug use amongst offenders entering prison is on the increase, mirroring the rising levels of drug use generally in the community[3]. This is a problem for prisons not only in Indonesia but in many countries such as Turkey[6], European countries, and America.[3].

This reality is what caused Indonesian detention centers and prisons to also provide narcotics rehabilitation programs. To be able to carry out narcotics rehabilitation, detention centers and prisons must meet the requirements or criteria, including having trained correctional officers, special rooms, clinics, and other supporting facilities. In addition, the implementation of narcotics rehabilitation involves inter-sectional cooperation between correctional officers who come from different sections, such as medical staff, coaching officers, security officers, and correctional advisers. The competencies of officers are also diverse and multi-disciplinary, such as medical, social science, psychology, and nursing. As many stakeholders as possible should be involved at the outset. Involving them in the process will provide a forum in which concerns and problems (both actual and perceived) can be discussed.[3].

Based on the results of research conducted by the Law and Human Rights Research and Development Agency in collaboration with the National Narcotics Agency on the effectiveness of rehabilitation of narcotics abusers in the Correctional Implementation Unit in 2019, it is known that the implementation of narcotics rehabilitation has not been optimal, especially when targeting accuracy, integration and sustainability of the rehabilitation phase. One of the causes is the inadequate role of correctional advisers in the rehabilitation process as most of them do not know their roles and responsibilities in the narcotics rehabilitation process for prisoners[7]. This has attracted the attention of the author to find out the role of correctional advisers in the narcotics rehabilitation process, an effort which can affect the success of narcotics rehabilitation in prisons.

\section{RESEARCH METHOD}

This study uses an empirical and descriptive juridical approach to determine and describe how the implementation of laws and regulations related to the duties and functions of correctional advisers in the narcotics rehabilitation process for prisoners. Sources of data in this study consisted of primary data and secondary data. The primary data derived 
from field data, carried out through focus group discussions with correctional advisers from several correctional centers in South Jakarta, Central Jakarta, and Makassar Correctional Centers, as well as correctional officers from several correctional institutions such as Jakarta, Yogyakarta, Sungguminasa , and Banceuy Prison.

Meanwhile, the secondary data is in the form of relevant laws and regulations such as the correctional law, the narcotics law, and the implementing regulations for the implementation of rehabilitation at the Correctional UPT. In addition, literature in the form of books and journals on narcotics rehabilitation is also available. The data that has been collected is then processed through an editing process and classified systematically which is then analyzed.

\section{FINDINGS AND DISCUSSION}

\subsection{The Purposes and Stages of Narcotics Rehabilitation}

Various studies estimate that the percentage of narcotics abuse by prisoners in prison is higher than in the community and there is a tendency to continue to increase, reflecting the increase in drug use in society[3]. This indicates a process of Law enforcement or prison cannot automatically stop an addict from using narcotics. Therefore, in the correctional system, a correctional facility is not only to protect the community from people who commit crimes but are also often tasked with helping them to lead law-abiding lives on their release.

Rehabilitation of narcotics in prisons has 4 objectives. First, it provides services and guarantees of protection for prisoners. Second, it is aimed to restore and maintain the prisoner's health condition which includes biological, psychological, and social aspects of dependence on narcotics, psychotropic substances, and other addictive substances. Third, it increases the productivity and quality of life of prisoners. Fourth, it prepares the prisoners to be able to carry out their social functions.[8]

Narcotics rehabilitation for prisoners at the Correctional Unit is a form of guidance and treatment program specifically aimed at detainees and prisoners who have indicated drug dependence and potentially relapse. Normatively, the target participants for narcotics rehabilitation at the Correctional Unit follow the narcotics law which determines 3 criteria for people who must be rehabilitated [8]:

1. Narcotics addicts; people who use or abuse Narcotics and are in a state of dependence on Narcotics, Psychotropics, and other addictive substances both physically and psychologically.

2. Narcotics abusers; people who use narcotics without rights or against the law.

3. Victims of Narcotics Abuse; people who accidentally use Narcotics because they were persuaded, tricked, tricked, forced, or threatened to use Narcotics.

Narcotics rehabilitation for detainees and prisoners is divided into 3 types, namely[9]:

1. Medical Rehabilitation; a process of integrating treatment activities to free addicts from addiction to Narcotics.

2. Social Rehabilitation; a process of integrating recovery activities, both physically, mentally, and socially, so that the former Narcotics addict can return to carry out social functions in community life.

3. Post-rehabilitation; a follow-up care service provided to clients, namely former addicts, abusers, or victims of narcotics abuse who have completed medical rehabilitation and social rehabilitation to maintain their recovery.

The three types of rehabilitation are carried out by 3 correctional technical implementation units, namely a detention house implementing medical rehabilitation, a correctional institution carrying out medical and social rehabilitation, and a correctional center implementing post-rehabilitation.

The narcotics rehabilitation process at the Correctional UPT is carried out selectively, starting with the screening stage to identify prisoners who are still addicted to narcotics. Then, the assessment stages are carried out to determine the type of rehabilitation needed, followed by medical rehabilitation and social rehabilitation, and finally post-rehabilitation[9]: 
The Stages of Narcotics Rehabilitation

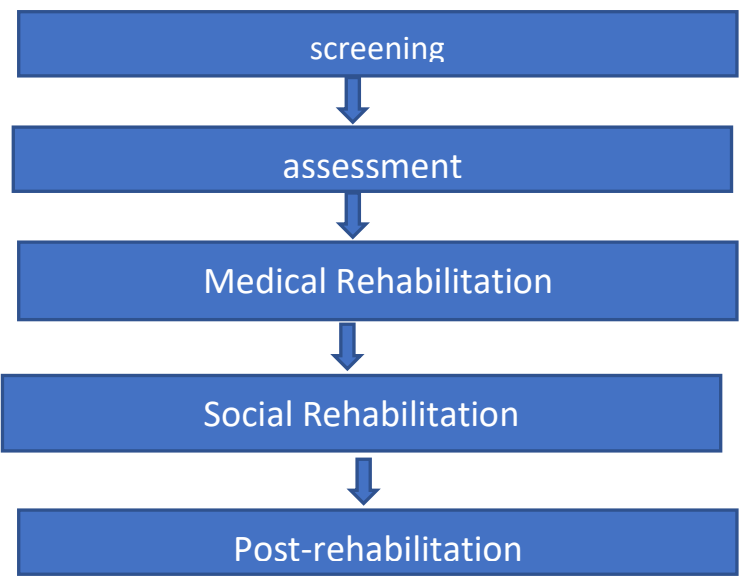

Source: Implementation Guidelines for Narcotics Rehabilitation at the Correctional Unit.

Ideally, every addict who follows rehabilitation must follow all stages of rehabilitation sequentially and must not be interrupted. Each stage of rehabilitation is interrelated and has a specific function and purpose as an integrated part. One of the principles for effective rehabilitation is the continuity of care for drug abusers to re-join the community.[10]. If one stage is not followed by the rehabilitation participants, it will affect the next stage and the rehabilitation goals cannot be achieved.

\subsection{The Role of Correctional Advisers in Narcotics Rehabilitation.}

A correctional adviser is an officer who is given the task, responsibility, authority, and right to carry out activities in the field of community guidance. The duties and functions of community guidance include [11]:

a. Community research is a research activity to determine the background of the life of the prisoners carried out by community supervisors.

b. Assistance is an effort made by community counselors in helping clients to overcome the problems they face so that clients can overcome these problems and achieve life change for the better.

c. Guidance is the provision of guidance to improve the quality of devotion to God Almighty, intellect, attitudes and behavior, physical and spiritual health of correctional clients. d. Supervision is the activity of observing and evaluating the implementation of service programs, fostering and guiding the assisted citizens of the correctional facility based on the recommendation of the social research report/stipulation / judge's decision.

The duties and functions of the correctional advisers are carried out in every stage of the rehabilitation process, namely: Pre Rehabilitation, Stages of rehabilitation, and post-rehabilitation. The following is the role of the correctional advisers in the rehabilitation stage:

1) First, in the pre-rehabilitation stage, correctional advisers have the task of determining prisoners who can participate in narcotics rehabilitation based on the prisoner's risk level)

The process of coaching prisoners in prisons is carried out based on the level of risk and the needs of each individual. The level of prisoner risk is divided into four, namely very high, high, medium, and low. The level of risk is the basis for the placement and development of prisoners. Based on the level of risk, correctional institutions are classified into 4 types, namely, super maximum security, maximum security, medium security, and minimum security.[12].

Correctional advisers are officers who give the task of measuring the level of risk of all prisoners and providing recommendations for guidance programs that should be given, by conducting initial community research used for[12]:

a. risk level assessment and placement recommendation for the convict to be placed in prisons in accordance with the classification;

b. providing recommendations for the needs of the Development of Prisoners following the prison classification level;

c. providing recommendations for the transfer of prisoners following the implementation of the Revitalization of Corrections

According to the Standard Minimum Rules for the Treatment of Prisoners, the purposes of classification prisoners shall be: ( a ) To separate those prisoners who, because of their criminal records or bad characters, are likely to exercise a bad influence; ( b ) To divide the prisoners into classes to facilitate their treatment with a view to their social rehabilitation. So far as possible separate institutions or separate sections of an institution shall be used for the treatment of the different classes of prisoners. As 
soon as possible after admission and after a study of the personality of each prisoner with a sentence of suitable length, a program of treatment shall be prepared for him in the light of the knowledge obtained about his individual needs, his capacities, and dispositions.[13].

In the process of narcotics rehabilitation, it is necessary that the correctional advisers conduct community research to address[3]:

- Risk: the 'intensity of the intervention should be matched to the risk of reoffending. Therefore prisoners assessed as having a higher risk of re-offending should receive the most intensive interventions and vice versa;

- Need: interventions should be targeted at risk factors for reoffending (also known as criminogenic needs). These risk factors, when targeted effectively, can be reduced thus reducing the risk of recidivism;

- Responsivity: this requires that interventions are matched to an offender's learning style and personality characteristics and the characteristics of the therapist/counselor.

Detention centers and prisons are less supportive of addicts/abusers and victims of abuse in the rehabilitation process. Because they are in the same environment/place with problematic people, including dealers and narcotics dealers, which can directly or indirectly affect their mental and psychological conditions to escape from drug dependence. However, the situation of detention centers and prisons is overcrowded and rooms are limited so that the separation of rehabilitation participants cannot be carried out optimally. This is where the role of correctional advisers is needed to provide recommendations to the Director-General of Corrections to arrange risk-based prisoners in such a way as to reduce the potential for disruption to the narcotics rehabilitation process.

To be able to identify the level of risk of prisoners, The correctional adviser uses the prisoner placement screening instrument to carry out a risk assessment to support the preparation of the placement society research. The screening instrument consists of four variables, namely the risk dimension variable, the length of sentence variable, the residual crime variable, and the crime variable[14].

The variable of the risk dimension, consisting of the first risk on security, aims to distinguish prisoners who have the potential to escape/attempt to escape. The second dimension of safety risk is to distinguish prisoners who have the potential/show dangerous behavior that threatens the safety of themselves, other prisoners, and officers, thus requiring special protection. The third dimension of risk is the safety of the coaching process, which aims to distinguish prisoners who have the potential not to follow/violate applicable regulations during the coaching period. The four dimensions of risk on stability aim to distinguish prisoners who have the potential to use their network to commit criminal acts in society even though they are undergoing a period of training. In addition, this dimension also sees prisoners who have the influence to influence correctional officers, judges, investigators, public prosecutors, or other parties to commit violations of the law.

The variable of the duration of punishment aims to consider the length of criminal sanctions imposed by the judge regarding the severity of the crime based on evidence in the trial process. The remaining variable of punishment is intended to consider how long the prisoner has received guidance in the correctional facility as well as to consider the time of release and implementation of the reintegration process. Meanwhile, the crime variable aims to consider the categories of criminal acts committed by a person based on the weighting of the predetermined criminal acts.

Ideally, rehabilitation participants are prisoners with minimum and medium risk levels, while for those with high-risk levels such as big dealers and distributors, rehabilitation is carried out specifically and separately at Super Maximum and Maximum security prisons. Based on data from the Directorate General of Correctional, the number of prisoners categorized as dealers/dealers was 88,625 while the users were 46,085.[2]. If referring to the narcotics law, prisoners who are categorized as users should be placed in the Special Narcotics Prison. However, this cannot be implemented because until now there are only 24 prisons specifically for narcotics throughout Indonesia and not yet in every province / regional office. Besides that, the institutional structure of Narcotics Prison is not devoted to carrying out its duties and functions as a narcotics rehabilitation prison.[15].

Based on the description above, in the prerehabilitation stage, the responsibility of the correctional advisers is quite heavy. They must be able to extract information from prisoners as accurately as possible, this process is quite difficult because there is a tendency for prisoners to be closed 
and unwilling to convey information about themselves or their crimes. Special skills and methods are needed so that inmates believe and provide truthful information. The results of community research that determine the placement of prisoners can minimize disturbances in prison security and order that can affect the rehabilitation process. At this stage, the correctional adviser must also be able to provide input to the prison regarding the development program plan in accordance with the needs of the prisoner.

2) Second, at the rehabilitation implementation stage,

The correctional advisers acting as an assistant team in charge of conducting community research to find out the profile of prisoners and their background on narcotics use as well as to evaluate the development of prisoners participating in rehabilitation.

At this stage, the correctional advisers act as an assessor officer who is part of the rehabilitation assessment team, Assessment services identify prisoners who require a drug treatment intervention and the suitability of a specific intervention for the individual prisoner. Assessment is an ongoing process that evaluates both the prisoner's progress in treatment and the effectiveness of the intervention, which if it is "not working" can be changed. Ideally, on arrival, all prisoners should receive a general health assessment, including an initial assessment for drug dependency. [3]. A planned assessment is one of the principles for effective narcotics rehabilitation, an individual's treatment and services plan must be assessed continually and modified as necessary to ensure that it meets his or her changing needs. [10]

Correctional advisers carry out initial coaching community research to gather data and information from prisoners, their families, and their environment, both at the time of starting, during undergoing, until the completion of rehabilitation. This is to determine the background of the causes of narcotic abuse disorders, to know the physical and psychological impacts, and to plan for rehabilitation therapy. At this stage, the correctional adviser makes 3 types of social research, namely Early Development Community Research, Assimilation, and Integration.

At this stage the role of correctional advisers is also to provide assistance and guidance to prisoners and their families, to provide information on narcotics rehabilitation, and encourage awareness of prisoners through spiritual, individual, and social approaches so that they are willing to change and are no longer dependent on narcotics. Because most of the prisoners still do not know and understand the importance of narcotics rehabilitation, especially about social rehabilitation.[16]. Family involvement with prisoners who take part in rehabilitation has a positive impact on rehabilitating the participants, and must be included in every stage of rehabilitation. An assessment must be carried out on the families of the rehabilitation participants so that the family knows and can contribute to the recovery of the rehabilitation participants. It can motivate rehabilitation participants to take part in narcotics rehabilitation.[15].

3) Third, the post-rehabilitation stage, acting as an addiction counselor who provides addiction counseling and education to clients and their families to prevent relapse.

The post-rehabilitation stage is a continuation of the medical and social rehabilitation phase carried out by prisoners who are currently participating in the assimilation and integration program. The postrehabilitation stage is carried out at the Correctional Center to make prisoners (correctional clients) recover, productively and function socially.

At this stage, the correctional advisers act as addiction counselor to mentoring and development when the prisoner is serving his sentence outside the prison. Mentoring is defined as a dynamic interaction between correctional clients and correctional advisers, in the form of addiction counseling to jointly face various challenges in recovery management. In the end, correctional clients can maintain their recovery and do not return to using narcotics when they return to society[9]. The recovery condition can be maintained if the mentoring process is carried out continuously by involving the family and the community.

The development phase is a recovery effort to improve the quality of life, life, and livelihoods during recovery which includes bio-psycho-socialspiritual and economic. The development phase is needs-basis, carried out activities to meet their needs, namely the need for education, vocational, religious, health, and business services [9].

The post-rehabilitation process can also involve other agencies, both government and nongovernmental organizations, which can help prisoners live economically, socially, and healthily during the integration process into society and maintain recovery from drug dependence. 
All three roles of correctional advisers mentioned above are to ensure accuracy of targeting and the sustainability of the rehabilitation phase. Rehabilitation will be effective provided that the rehabilitation participants are prisoners categorized as addicts and abusers, and follow all the stages of rehabilitation sequentially.

\section{CONCLUSION}

Narcotics rehabilitation is a guidance program following the needs of prisoners categorized as addicts, abusers, and victims of narcotics abusers so that they recover from drug dependence, function socially and productively. Correctional advisers have a strategic role in each stage of rehabilitation that can affect the success of narcotics rehabilitation in prisons, because the work of correctional advisers is used as a basis for planning, implementing, and supervising each stage of rehabilitation.

Correctional advisers perform 3 roles. First, they act as an assistant for the placement and guidance of prisoners. Second, they are rehabilitation assessor officers who are tasked with assisting inmates while attending rehabilitation. Third, they play a role as an addiction counselor or recovery agent whose function is to keep inmates from using narcotics and to help them be productive and function socially during the integration process into society.

To be able to carry out this role, correctional advisers must have adequate competence regarding narcotics rehabilitation, therefore the DirectorGeneral of Corrections in collaboration with the National Narcotics Agency should provide education and training on narcotics rehabilitation, as well as increasing the number of correctional advisers and correctional centers.

\section{REFERENCES}

[1] Badan Narkotika Nasional, Indonesia Drugs Report Tahun 2019. Jakarta: Badan Narkotika Nasional, 2019.

[2] Direktorat Jenderal Pemasyarakatan, "Direktorat Jenderal Pemasyarakatan, "Http://Smslap.Ditjenpas.Go.Id/Public/Krl/ Current/Monthly/Year/2019/Month/10," 2020. .

[3] United Nation Office On Drugs and Crime, "Drug Dependence Treatment interventions for Drug Users In Prison,” 2008.

[4] Insan Firdaus, "Policy Analysis on
Optimizing Narcotics Rehabilitation Implementation in Corrective Technical Services Uni," J. Ilm. Kebijak. Huk., vol. 14, no. 3, pp. 469-492, 2020.

[5] Novita Sari, "Penerapan Asas Ultimum Remedium Dalam Penegakan Hukum Tindak Pidana Penyalahgunaan Narkotika," J. Penelit. Huk. JURE, vol. 17, no. 3, pp. 351-363, 2017.

[6] Tuba Topçuoğlu, "Effectiveness of Prisonbased Drug Treatment Programs: A Systematic Review of Meta-analyses," ADDICTA TURKISH J. Addict., vol. 3, no. 1, pp. 110-124, 2016.

[7] Badan Narkotika Nasional dan Balitbang Hukum dan HAM, Riset Operasional Efektivitas Pelaksanaan Rehabilitasi Penyalahguna Narkotika Di Unit Pelaksana Teknis Pemasyarakatan. Jakarta: Badan Narkotika Nasional, 2019.

[8] Peraturan Menteri Hukum dan Hak Asasi Manusia Nomor 12 tahun 2017 tentang Penyelenggaraan Layanan Rehabilitasi Narkotika Bagi Tahanan dan Warga Binaan Pemasyarakatan. 2017.

[9] Keputusan Direktur Jenderal Pemasyarakatan Kementerian Hukum Dan Hak Asasi Manusia Republik Indonesia Nomor Pas-985.Pk.01.06.04 Tahun 2018 Tentang Petunjuk Pelaksanaan Layanan Rehabilitasi Narkotika Bagi Tahanan Dan Warga Binaan Pemasyarakatan Di Upt Pema.

[10] NIDA, "Principles. National Institute on Drug Abuse website.

https://www.drugabuse.gov/publications/pri nciples-drug-abuse-treatment-criminaljustice-populations-research-basedguide/principles. June 16, 2020 Accessed October 20, 2020.," 2020. .

[11] Peraturan Menteri Pemberdayaan Aparatur Negara dan Reformasi Birokrasi Nomor 22 tahun 2016, tentang Jabatan Fungsional Pembimbing Kemasyarakatan. .

[12] Peraturan Menteri Hukum dan HAM Republik Indonesia Nomor 35 Tahun 2018, Revitalisasi Penyelenggaraan Pemasyarakatan. .

[13] UNODC, "https://www.unodc.org/pdf/criminal_justic e/UN_Standard_Minimum_Rules_for_the_ Treatment_of_Prisoners.pdf.”. 
[14] Keputusan Direktur Jenderal Pemasyarakatan Kementerian Hukum Dan Hak Asasi Manusia Republik Indonesia Nomor : Pas-58.Ot.02.02 Tahun 2019 Tentang Instrumen Screening Penempatan Narapidana. .

[15] Badan Penelitian dan Pengembangan Hukum dan HAM RI, "Evaluasi Rehabilitasi Narkotika bagi Tahanan dan Warga Binaan Pemasyarakatan di UPT Pemasyarakatan," Jakarta, 2020.

[16] Vivi Sylviani Biafri, "Implementation Of The Therapeutic Community Rehabilitation For Narcotic Prisoners At Narcotics Special Prison Clas II A Jakarta," Berumpun, Int. J. Soc. Polit. Humanit., vol. 3, no. 1, pp. 2338, 2020, [Online]. Available: https://doi.org/10.33019/\%0Aberumpun.v2i 2.23 . 